\title{
DINAMIKA SENTRALISASI DAN DESENTRALISASI DI INDONESIA
}

\author{
Rira Nuradhawati \\ rira.nuradhawati@lecture.unjani.ac.id \\ Dosen Program Pascasarjana Magister Ilmu Pemerintahan \\ Universitas Jenderal Achmad Yani
}

\begin{abstract}
Abstrak
Sentralisasi dan desentralisasi adalah dua istilah yang tidak lagi asing di telinga kita saat ini. Dalam praktik kehidupan berbangsa dan bernegara, sentralisasi dan desentralisasi adalah sebuah kontium. Karena tidak ada sebuah negara yang secara penuh hanya menggunakan azas sentralisasi saja dalam penyelenggaraan pemerintahannya. Sebaliknya juga tidak mungkin penyelenggaraan pemerintahan hanya didasarkan pada azas desentralisasi saja.

Sentralisasi adalah memusatkan seluruh wewenang kepada sejumlah kecil manajer atau yang berada di posisi puncak pada suatu struktur organisasi. Sentralisasi banyak digunakan pada pemerintahan lama di Indonesia sebelum adanya otonomi daerah. Sedangkan desentralisasi dapat diartikan sebagai pengalihan tanggung jawab, kewenangan, dan sumber-sumber daya (dana, manusia dan lain-lain) dari pemerintah pusat ke pemerintah daerah.

Berubahnya sentralisasi menjadi desentralisasi membawa perubahan dalam sistem pemerintahan diantaranya Pilkada langsung dan Pemilu Presiden. Meskipun dirasa sebagai perubahan ke arah positif tetap saja timbul nada pesimis dan pandangan negatif dari berbagai kalangan tentang pelaksanaan pilkada di Indonesia tidak meniadakan arti pentingnya institusi ini dalam konsolidasi demokrasi di era desentralisasi ini.
\end{abstract}

Kata Kunci : Sentralisasi, Desentralisasi, Pemerintahan Daerah

\section{PENDAHULUAN}

Dalam praktek kehidupan bernegara, sentralisasi dan desentralisasi adalah sebuah kontinuum. Tidak ada sebuah negara yang secara penuh hanya menggunakan azas sentralisasi saja dalam penyelenggaraan pemerintahannya. Sebaliknya juga tidak mungkin penyelenggaraan pemerintahan hanya didasarkan pada azas desentralisasi saja.

Beberapa kewenangan klasik memang lazimnya hanya dilakukan secara sentralisasi seperti kewenangan luar negeri, kewenangan pertahanan dan kewenangan peradilan Moneter dalam arti mencetak uang, menentukan nilai uang, 
dan sebagainya.. Meskipun dalam prakteknya juga terdapat azas dekonsentrasi yang merupakan penghalusan dari azas sentralisasi. Titik temu keseimbangan antara sentralisasi dan desentralisasi dalam penyelenggaraan pemerintahan dapat dikaji dalam berbagai aspek, misalnya saja dalam aspek pembagian kewenangan, aspek intervensi pusat terhadap daerah, aspek keterlibatan daerah di tingkat pusat, dan aspek pembagian (perimbangan) sumberdaya keuangan.

Di Indonesia sejak tahun 1998 hingga baru-baru ini, pandangan politik yang dianggap tepat dalam wacana publik adalah bahwa desentralisasi merupakan jalan yang meyakinkan, yang akan menguntungkan daerah. Pandangan ini diciptakan oleh pengalaman sejarah selama masa Orde Baru di mana sentralisme membawa banyak akibat merugikan bagi daerah. Sayang, situasi ini mengecilkan kesempatan dikembangkannya suatu diskusi yang sehat bagaimana sebaiknya desentralisasi dikembangkan di Indonesia. Jiwa desentralisasi di Indonesia adalah "melepaskan diri sebesarnya dari pusat" bukan "membagi tanggung jawab kesejahteraan daerah".

Sentralisasi dan desentralisasi tidak boleh ditetapkan sebagai suatu proses satu arah dengan tujuan pasti. Pertama- tama, kedua "sasi" itu adalah masalah perimbangan. Artinya, peran pemerintah pusat dan pemerintah daerah akan selalu merupakan dua hal yang dibutuhkan. Tak ada rumusan ideal perimbangan. Selain proses politik yang sukar ditentukan, seharusnya ukuran yang paling sah adalah argumen mana yang terbaik bagi masyarakat.

Masalah sentralisasi dan desentralisasi bukan lagi dipandang sebagai persoalan penyelenggara negara saja. Pada akhirnya kekuatan suatu bangsa harus diletakkan pada masyarakatnya. Saat ini di banyak wilayah, politik lokal dikuasai selain oleh orang-orang partai politik juga kelompok-kelompok yang menjalankan prinsip bertentangan dengan pencapaian tujuan kesejahteraan umum. Kekuatan kelompok pro pembaruan lemah di banyak daerah dan langsung harus berhadapan dengan kekuatan-kekuatan politik lokal dengan kepentingan sempit.

Sesuai dengan semangat reformasi yang terjadi pada tahun 1998, format penyelenggaraan pemerintahan daerah di Indonesia juga mengalami perubahan dari pendulum sentralisasi ke pendulum desentralisasi. Hal ini dapat dianalisis 
misalnya dari format pembagian kewenangan yang berpola residu dan peletakkan lokus otonomi daerah pada tingkat kabupaten/kota. Hal ini dianut secara tajam di dalam UU No 22 tahun 1999, dan mengalami pergeseran kembali di dalam UU No 32 tahun 2004. dan UU No 23 Tahun 2014 dan terakhir UU No 9 Tahun 2015. Berbagai kewenangan yang semula dimiliki oleh pemerintah pusat dan propinsi diserahkan kepada daerah kabupaten/kota. Sesuai dengan tujuannnya, maka penguatan otonomi daerah di tingkat kabupaten/kota dimaksudkan untuk meningkatkan demokrasi partisipatif (participatory democracy) dan efisiensi dalam penyelenggaraan pemerintahan. Dengan kewenangan yang dimiliki, kabupaten/kota dapat menentukan sendiri prioritas pembangunan daerah sesuai dengan potensi yang dimiliki.

Berbagai Peraturan Daerah yang semula harus disetujui oleh pemerintah pusat terlebih dahulu, dapat ditetapkan oleh Kepala Daerah secara mandiri. Hal yang sama juga terjadi di berbagai perizinan investasi, hal mana daerah dapat menetapkan dan memberikan izin tanpa persetujuan dari pemerintah pusat. Dengan otonomi daerah diharapkan prosedur investasi akan semakin mudah sehingga potensi daerah dapat dimanfaatkan sebesar-besarnya untuk kemakmuran rakyat.

\section{Konsep dan Teori Sentralisasi}

Sentralisasi adalah memusatkan seluruh wewenang kepada sejumlah kecil manajer atau yang berada di posisi puncak pada suatu struktur organisasi. Sentralisasi banyak digunakan pada pemerintahan lama di Indonesia sebelum adanya otonomi daerah.

Sentralisasi berasal dari bahasa inggris yang berakar dari kata Centre yang artinya adalah pusat atau tengah. Sentralisasi adalah memusatkan seluruh wewenang kepada sejumlah kecil manajer atau yang berada di posisi puncak pada suatu struktur organisasi. Sentralisasi banyak digunakan pada pemerintahan lama di Indonesia sebelum adanya otonomi daerah.

Secara terminology sentralisasi : 
1. B.N. Marbun dalam bukunya Kamus Politik mengatakan bahwa sentralisasi yang paham nya kita kenal dengan sentralisme adalah pola kenegaraan yang memusatkan seluruh pengambilan keputusan politik ekonomi, social di satu pusat

2. Sentralisasi adalah seeluruh wewenang terpusat pada pemerintah pusat.

Berdasarkan definisi diatas bisa kita interpretasikan bahwa sistem sentralisasi itu adalah bahwa seluruh decition (keputusan/Kebijakan) dikeluarkan oleh pusat, daerah tinggal menunggu instruksi dari pusat untuk melaksanakan kebijakan-kebijakan yang telah digariskan menurut uu. menurut ekonomi manajemen sentralisasi adalah memusatkan semua wewenang kepada sejumlah kecil manager atau yang berada di suatu puncak pada sebuah struktur organisasi. sentralisasi banyak digunakan pemerintah sebelum otonomi daerah. kelemahan sistem sentralisasi adalah dimana sebuah kebijakan dan keputusan pemerintah daerah dihasilkan oleh orang-orang yang berada di pemerintah pusat sehingga waktu untuk memutuskan suatu hal menjadi lebih lama.

Secara teoritis sentralisasi memiliki keunggulan antara lain :

1. Organisasi menjadi lebih ramping dan efisien. seluruh efektivitas organisasi terpusat sehingga pengambilan keputusan lebih mudah.

2. Perencanaan dan pengembangan organisasi lebih terintegerasi. Tidak perlu jenjang koordinasi yang terlalu jauh antara unit pengambilan keputusan dan yang akan melaksanakan atau terpengaruh oleh pengambilan keputusan tersebut.

3. Peningkatan resource sharing dan sinergi. Sumberdaya dapat dikelola secara lebih efisien karena dilakukan lebih terpusat.

4. Pengurangan redundancies aset dan fasilitas lain. Satu aset dapat dipergunakan secara bersama-sama tanpa harus menyediakan aset yang sama untuk pekerjaan yang berbeda-beda.

5. Perbaikan koordinasi. Koordinasi menjadi lebih mudah karena adanya unity of command.

6. Pemusatan expertise. Keahlian dari anggota organisasi dapat dimanfaatkan secara maksimal karena pimpinan dapat memberi wewenang. 
Namun sentralisasi juga memiliki kelemahan diantaranya adalah :

1. Kemungkinan penurunan kecepatan pengambilan keputusan dan kualitas keputusan. Pengambilan keputusan dengan pendekatan sentralisasi seringkali tidak mempertimbangkan faktor-faktor yang sekiranya berpengaruh terhadap pengambilan keputusan tersebut.

2. Demotivasi dan disinsentif bagi pengembangan unit organisasi. Anggota organisasi sulit mengembangkan potensi dirinya karena tidak ada wahana dan dominasi pimpinan yang terlalu tinggi.

3. Penurunan kecepatan untuk merespon perubahan lingkungan. Organisasi sangat bergantung pada daya respon sekelompok orang saja.

4. Peningkatan kompleksitas pengelolaan. Pengelolaan organisasi akan semakin rumit karena banyaknya masalah pada level unit organisasi yang di bawah.

5. Perspektif luas tapi kurang mendalam. Pimpinan organisasi akan mengambil keputusan berdasar perspektif organisasi secara keseluruhan tapi tidak atau jarang mempertimbangkan implementasinya akan seperti apa.

\section{Dampak Positif Dan Negatif Sentralisasi}

a. Segi Ekonomi

Dari segi ekonomi, efek positif yang diberikan oleh sistem sentralisasi ini adalah perekonomian lebih terarah dan teratur karena pada sistem ini hanya pusat saja yang mengatur perekonomian. Sedangkan dampak negatifnya adalah daerah seolah-olah hanya dijadikan sapi perahan saja dan tidak dibiarkan mengatur kebijakan perekonomiannya masing-masing sehingga terjadi pemusatan keuangan pada Pemerintah Pusat.

b. Segi Sosial Budaya

Dengan dilaksanakannya sistem sentralisasi ini, perbedaan-perbedaan kebudayaan yang dimiliki bangsa Indonesia dapat dipersatukan. Sehingga setiap daerah tidak saling menonjolkan kebudayaan masing-masing dan lebih mengutamakan semboyan Bhineka Tunggal Ika yang dimiliki bangsa Indonesia. 
Sedangkan dampak negatif yang ditimbulkan sistem ini adalah pemerintah pusat begitu dominan dalam menggerakkan seluruh aktivitas negara. Dominasi pemerintah pusat terhadap pemerintah daerah telah menghilangkan eksistensi daerah sebagai tatanan pemerintahan lokal yang memiliki keunikan dinamika sosial budaya tersendiri, keadaan ini dalam jangka waktu yang panjang mengakibatkan ketergantungan kepada pemerintah pusat yang pada akhirnya mematikan kreasi dan inisiatif lokal untuk membangun lokalitasnya.

c. Segi Keamanan Dan Politik

Dampak positif yang dirasakan adalah keamanan lebih terjamin karena pada masa diterapkannya sistem ini, jarang terjadi konflik antar daerah yang dapat mengganggu stabilitas keamanan nasional Indonesia. Tetapi sentralisasi juga membawa dampak negatif yaitu menonjolnya organisasi-organisasi kemiliteran, sehingga organisasi kemiliteran tersebut memiliki hak yang lebih daripada organisasi yang lain.

Dampak positif yang dirasakan dalam bidang politik adalah pemerintah daerah tidak perlu pusing-pusing pada permasalahan yang timbul akibat perbedaan pengambilan keputusan, karena seluruh keputusan dan kebijakan dikoordinasi seluruhnya oleh pemerintah pusat. Sehingga keputusan yang dihasilkan dapat terlaksana secara maksimal karena pemerintah daerah hanya menerima saja.

Dampak negatifnya adalah terjadinya kemandulan dalam diri daerah karena hanya terus bergantung pada keputusan yang diberikan oleh pusat, selain itu waktu yang dihabiskan untuk menghasilkan suatu keputusan atau kebijakan memakan waktu yang lama dan menyebabkan realisasi dari keputusan tersebut terhambat.

\section{Konsep Dan Teori Desentralisasi}

Indonesia saat ini sedang menjalankan upaya desentralisasi yang paling cepat dan meluas yang pernah ada dalam sejarah, dimotori oleh kekuatankekuatan politik regional yang muncul sejak jatuhnya pemerintahan Suharto yang sentralistik dan otoriter. Walaupun besar dan beragam, Indonesia pada waktu itu memiliki sistem administrasi dan fiskal yang sangat terpusat. Dalam fiskal 1999, 
misalnya, pemerintah pusat mengumpulkan 94 persen dari pendapatan pemerintah secara umum dan sekitar 60 persen dari pengeluaran daerah dibiayai oleh transfer dari pusat. Sistem ini memperlemah hubungan antara permintaan lokal dan pengambilan keputusan dalam hal pelayanan publik lokal, mengurangi akuntabilitas lokal, dan membuat alokasi yang bersifat ad hoc dari sumberdaya fiskal di seluruh daerah.

Di masa lalu, ketidakpuasan timbul akibat pengendalian pemerintah pusat terhadap penghasilan dari sumber daya alam di daerah serta kurang sensitifnya pemerintah terhadap perbedaan antardaerah; ketidakpuasan ini kemudian memunculkan permintaan yang kuat akan pembagian kekuasaan. Berbagai proposal untuk desentralisasi fiskal telah dibuat sejak awal 1970-an (Delay et.al, 1995; Devas, 1997; Rohdehwold, 1995), namun elemen-elemen utamanya tidak pernah terlaksana. Dipicu oleh krismon dan pergolakan politik yang timbul setelah itu, Indonesia sekarang mengambil langkah raksasa dalam desentralisasi politik dan fiskal. Pemerintah merespon kepada permintaan akan desentralisasi yang semakin keras ketika DPR dengan cepat menyetujui dua undang-undang di bulan April 1999 dengan menetapkan tanggal 1 Januari 2001 sebagai mulai dilaksanakannya desentralisasi yang drastis, yang bisa dikatakan sebagai "big bang” ("ledakan keras").

Elemen utama dari desentralisasi ini adalah:

1. Undang-undang No. 22 Tahun 1999 yang kemudian diubah menjadi UU No. 32 Tahun 2004 tentang Pemerintahan Daerah yang mengatur wewenang serta tanggung jawab politik dan administratif pemerintah pusat, provinsi, kota, dan kabupaten dalam struktur yang terdesentralisasi.

2. Undang-undang No. 25 Tahun 1999 yang kemudian diubah menjadi UU No. 33 Tahun 2004 tentang Perimbangan Keuangan antara Pemerintah Pusat dan Pemerintah Daerah memberikan dasar hukum bagi desentralisasi fiskal dengan menetapkan aturan baru tentang pembagian sumber-sumber pendapatan dan transfer antarpemerintah. 
3. Selanjutnya adalah Undang-undang No 23 tahun 2014 tentang Pemerintahan Daerah yang mengalami perubahan dengan Undang-undang No 9 tahun 2015 tentang Perubahan Kedua Atas Undang-undang No 23 tahun 2004 tentang Pemerintahan Daerah

Undang-undang di atas mencakup semua aspek utama dalam desentralisasi fiskal dan administrasi. Berdasarkan kedua undang-undang ini, sejumlah besar fungsi-fungsi pemerintahan dialihkan dari pusat ke daerah sejak awal 2001 dalam banyak hal melewati provinsi. Berdasarkan undang-undang ini, semua fungsi pelayanan publik kecuali pertahanan, urusan luar negeri, kebijakan moneter dan fiskal, urusan perdagangan dan hukum, telah dialihkan ke daerah otonom. Kota dan kabupaten memikul tanggung jawab di hampir semua bidang pelayanan publik seperti kesehatan, pendidikan, dan prasarana; dengan provinsi bertindak sebagai koordinator. Jika ada tugas-tugas lain yang tidak disebut dalam undangundang, hal itu berada dalam tanggung jawab pemerintah daerah.

Pergeseran konstitusional ini diiringi oleh pengalihan ribuan kantor wilayah (perangkat pusat) dengan sekitar dua juta karyawan, pelaksanaan pemilihan kepala daerah secara langsung mulai tahun 2005. Lebih penting lagi, Dana Alokasi Umum atau DAU yang berupa block grant menjadi mekanisme utama dalam transfer fiskal ke pemerintah daerah, menandai berakhirnya pengendalian pusat terhadap anggaran dan pengambilan keputusan keuangan daerah. DAU ditentukan berdasarkan suatu formula yang ditujukan untuk memeratakan kapasitas fiskal pemerintah daerah guna memenuhi kebutuhan pengeluarannya. Pemerintah Pusat juga akan berbagi penerimaan dari sumber daya alam - gas dari daratan (onshore), minyak dari daratan, kehutanan dan perikanan, dan sumber-sumber lain — dengan pemerintah daerah otonom.

Dengan adanya undang-undang pemerintahan daerah ini memberikan angin segar dengan adanya perubahan-perubahan yang mencerminkan realitas politik bahwa warga negara Indonesia kebanyakan menghendaki peran yang lebih besar dalam mengelola urusan sendiri. Meskipun demikian, tata pemerintahan lokal yang baik pada saat ini belum dapat dilaksanakan di Indonesia, meskipun 
sistem desentralisasi telah dilaksanakan. Periode yang tengah dialami oleh Indonesia pasca dikeluarkannya UU No. 22/ 1999 yang kemudian disempurnakan dengan keluarnya UU No 32/2004 dan seterusnya yaitu periode transisi atau masa peralihan sistem. Artinya, secara formal sistem telah berubah dari sentralistik menjadi desentralisasi. Tetapi, mentalitas dari aparat pemerintah baik pusat maupun daerah masih belum mengalami perubahan yang mendasar. Hal ini terjadi karena perubahan sistem tidak dibarengi penguatan kualitas sumber daya manusia yang menunjang sistem pemerintahan yang baru. Pelayanan publik yang diharapkan, yaitu birokrasi yang sepenuhnya mendedikasikan diri untuk untuk memenuhi kebutuhan rakyat -sebagai pengguna jasa- adalah pelayanan publik yang ideal. Untuk merealisasikan bentuk pelayanan publik yang sesuai dengan asas desentralisasi diperlukan perubahan paradigma secara radikal dari aparat birokrasi sebagai unsur utama dalam pencapaian tata pemerintahan lokal

Desentralisasi saat ini telah menjadi azas penyelenggaraan pemerintahan yang diterima secara universal dengan berbagai macam bentuk aplikasi di setiap negara. Hal ini sesuai dengan fakta bahwa tidak semua urusan pemerintahan dapat diselenggarakan secara sentralisasi, mengingat kondisi geografis, kompleksitas perkembangan masyarakat, kemajemukan struktu sosial dan budaya lokal serta adanya tuntutan demokratisasi dalam penyelenggaraan pemerintahan.

Desentralisasi memiliki berbagai macam tujuan. Secara umum tujuan tersebut dapat diklasifikasi ke dalam dua variabel penting, yaitu pertama peningkatan efisiensi dan efektivitas penyelenggaraan pemerintahan (yang merupakan pendekatan model efisiensi struktural/structural efficiency model) dan kedua peningkatan partisipasi masyarakat dalam pemerintahan dan pembangunan (yang merupakan pendekatan model partisipasi/participatory model). Setiap negara lazimnya memiliki titik berat yang berbeda dalam tujuan-tujuan desentralisasinya tergantung pada kesepakatan dalam konstitusi terhadap arah pertumbuhan (direction of growth) yang akan dicapai melalui desentralisasi.

Desentralisasi mencakup beberapa makna yang mencakup hal-hal berikut yaitu distribusi kewenangan dari pusat ke daerah, yang berarti distribusi kewenangan pemerintah pusat dalam bentuk kewenangan dekonsentrasi dan 
delegasi kewenangan. Yang pertama adalah pemberian kewenangan ke organ pemerintah pusat di daerah dan yang kedua adalah delegasi kewenangan dari pemerintah pusat ke organ lokal. Sebaliknya, devolusi kewenangan berarti perpindahan kewenangan dari pemerintah pusat ke daerah yang disertai dengan realokasi sumber penerimaan dan pembiayaan.

Dalam hal ini, reformasi desentralisasi mensyaratkan adanya reformasi dalam hubungan pusat dan daerah disertai otonomi pemerintahan daerah. Ketika pemerintah daerah dan masyarakat lokal mencapai tingkatan otonomi, keduanya dapat memberdayakan sumberdaya lokal demi mencapai taraf pembangunan ekonomi yang tinggi di daerahnya masing-masing. Perwujudan dari desentralisasi ini adalah otonomi daerah yaitu hak, wewenang, dan kewajiban daerah untuk mengatur dan mengurus rumah tangganya sendiri sesuai dengan peraturan perundang-undangan yang berlaku. Pada tingkat yang terendah, otonomi berarti mengacu pada perwujudan free will yang melekat pada diri-diri manusia sebagai satu anugerah paling berharga dari Tuhan (Piliang, 2003).

Dalam banyak kasus dan contoh, desentralisasi pada level kota/kabupaten mempunyai kecenderungan untuk mencapai tingkat pemberdayaan yang baik. Secara umum, pemerintah kabupaten/kota adalah tingkat pemerintah yang mempunyai daya jangkau yang dekat dengan masyarakat lokal namun mempunyai daya wilayah yang cukup untuk memberdayakan sumber daya lokal. Hal ini berarti bahwa pemerintah kabupaten/kota merupakan kunci penting sebagai basis dari pengembangan tata pemerintahan lokal dan pemberdayaan pada tingkat kabupaten/kota mempunyai fungsi penting terhadap masyarakat lokal yang turut serta dalam tata pemerintahan lokal. Sementara itu, desentralisasi pada tingkat propinsi dalam banyak hal bertujuan untuk mencapai pembangunan ekonomi di tingkat propinsi and pembangunan kapasitas untuk mendukung dan membantu desentralisasi di tingkat kabupaten/kota.

Dalam konteks Indonesia, Desentralisasi telah menjadi konsensus pendiri bangsa. Pasal 18 UUD 1945 yang sudah diamandemen dan ditambahkan menjadi pasal 18, 18A dan 18B memberikan dasar dalam penyelenggaraan desentralisasi. Negara Kesatuan Republik Indonesia dibagi atas daerah-daerah Propinsi, dan 
daerah provinsi itu dibagi atas Kabupaten dan Kota yang masing-masing mempunyai pemerintahan daerah. Amanat dan Konsensus Konstitusi ini telah lama dipraktekkan sejak Kemerdekaan Republik Indonesia dengan berbagai pasang naik dan pasang surut tujuan yang hendak dicapai melalui desentralisasi tersebut.

Desentralisasi sebenarnya adalah istilah dalam keorganisasian yang secara sederhana di definisikan sebagai penyerahan kewenangan. Dalam kaitannya dengan sistem pemerintahan Indonesia, desentralisasi akhir-akhir ini seringkali dikaitkan dengan sistem pemerintahan karena dengan adanya desentralisasi sekarang menyebabkan perubahan paradigma pemerintahan di Indonesia.

Desentralisasi juga dapat diartikan sebagai pengalihan tanggung jawab, kewenangan, dan sumber-sumber daya (dana, manusia dan lain-lain) dari pemerintah pusat ke pemerintah daerah. Dasar pemikiran yang melatarbelakanginya adalah keinginan untuk memindahkan pengambilan keputusan untuk lebih dekat dengan mereka yang merasakan langsung pengaruh program dan pelayanan yang dirancang dan dilaksanakan oleh pemerintah. Hal ini akan meningkatkan relevansi antara pelayanan umum dengan kebutuhan dan kondisi masyarakat lokal, sekaligus tetap mengejar tujuan yang ingin dicapai oleh pemerintah ditingkat daerah dan nasional, dari segi sosial dan ekonomi. Inisiatif peningkatan perencanaan, pelaksanaan, dan keuangan pembangunan sosial ekonomi diharapkan dapat menjamin digunakannya sumber-sumber daya pemerintah secara efektif dan efisien untuk memenuhi kebutuhan lokal.

\section{Desentraliasi dan Tata Pemerintahan Lokal}

Latar belakang dan asal muasal reformasi desentralisasi adalah tidak berfungsi dan gagalnya sistem pembuatan keputusan yang sentralistis dimana pemerintah pusat tidak dapat menyediakan solusi-solusi bagi tiap-tiap komunitas di tiap-tiap lokalitas yang beragam. Dalam hal ini reformasi desentralisasi mempunyai fokus pada perbedaan lokalitas dan mencoba mengembangkan kapasitas pemerintah daerah dalam memecahkan permasalahan-permasalahan di tingkat lokal. 
Selain itu adalah tidak efisiennya konsumsi sumberdaya lokal. Sistem alokasi yang tersentralisasi telah gagal dalam memberikan hasil yang efi sien dan efektif dalam hal pengeluaran pemerintah pusat dan daerah, contohnya adalah sistem alokasi penerimaan pajak. Pajak yang ditarik secara terpusat oleh pemerintah pusat dan sistem konsumsi sumberdaya lokal merupakan sistem yang sangat menguntungkan bagi pemerintah pusat untuk mengontrol pengeluaran lokal dan pembuatan kebijakan di daerah. Tidak mengherankan apabila pada masa orde baru, salah satu mekanisme sentralisasi kekuasaan oleh pemerintah pusat berpusat pada pengontrolan alokasi dana untuk pembangunan daerah.

Namun demikian, sistem tersebut dapat merusak hubungan antara penerimaan dan pengeluaraan di daerah dan masyarakat lokal tidak dapat mengawasi dan mengontrol keuangan pemerintah daerahnya masing-masing. Ketika masyarakat lokal cenderung untuk meminta banyak dari pemerintah daerah sehubungan dengan pelayanan publik dan lain sebagainya tanpa kesadaran akan biaya yang akan dikeluarkan oleh pemerintah daerah, tingkat kepuasan masyarakat akan aktivitas pemerintah daerah akan semakin berkurang seiring ketidakmampuan pemerintah daerah membiayai pelayanan publik yang diinginkan oleh masyarakat lokal. Hasilnya adalah kegagalan dalam alokasi sumberdaya lokal bagi masyarakat lokal itu sendiri.

Yang terakhir adalah kematangan sistem pemerintahan daerah dan masyarakat sipil di daerah. Di setiap daerah, dengan adanya tradisi mengenai tata pemerintahan lokal, pemerintah daerah dan masyarakat lokal memiliki pengalaman akan praktik tata pemerintahan yang baik seseuai dengan kondisi khusus masing-masing. Sangatlah wajar jika kemudian tiap daerah telah mempunyai modal yang cukup mengenai pelaksanaan dan strategi tata pemerintahan lokal untuk kemudian memperkaya konsep otonomi daerah.

Jalan yang terbaik untuk meminimalisasi persoalan yang diakibatkan gagalnya sistem yang tersentraliasi adalah reformasi desentralisasi. Desentralisasi dan otonomi diharapkan menjadi solusi yang tepat untuk berbagai persoalan yang ada di daerah. Asumsi dasar desentralisasi yaitu mendekatkan pelayanan dengan rakyat. Dengan sistem desentralisasi, pelayanan publik menjadi mudah 
direalisasikan mengingat adanya kedekatan antara penyedia layanan dan pengguna layanan. Terlebih lagi mengingat bentuk negara Indonesia sebagai negara kepulauan yang sulit dijangkau dan setiap wilayah memiliki karakteristik yang sangat berbeda.

Oleh karena itu, kebijakan otonomi daerah itu tidak hanya perlu dilihat kaitannya dengan agenda pengalihan kewenangan dari Pemerintah Pusat ke Pemerintah Daerah, tetapi juga menyangkut pengalihan kewenangan dari pemerintahan ke masyarakat. Justru inilah yang harus dilihat sebagai esensi pokok dari kebijakan otonomi daerah itu dalam arti yang sesungguhnya. Otonomi daerah berarti otonomi masyarakat di daerah-daerah yang diharapkan dapat terus tumbuh dan berkembang keprakarsaan dan kemandiriannya dalam iklim demokrasi dewasa ini.

Untuk mencapai tata pemerintahan lokal yang baik, terdapat beberapa prinsip utama yang harus diperhatikan.

a. Penciptaan demokrasi lokal adalah yang utama dimana dalam hal ini mencakup lembaga

b. Perwakilan lokal yang dipilih oleh masyarakat lokal, hak pilih bagi masyarakat lokal, partisipasi publik, dan lainnya.

c. Efisiensi dan efektifitas dari pemerintah daerah.

d. Prinsip rule of law termasuk di dalamnya due process of law dan prinsip keadilan.

e. Pemberantasan korupsi.

Di era desentralisasi, tata pemerintahan yang baik adalah standar minimum bagi pemerintah daerah. Selain itu, tata pemerintahan lokal yang menjalankan desentralisasi membutuhkan lebih banyak kapasitas dan kapabilitas karena tata pemerintah lokal dalam bentuk ini mempunyai kewenangan dan sumber daya yang besar dan untuk memberdayakan kewenangan dan sumber daya tersebut dibutuhkan kapasitas dan kapabilitas 
Untuk itu diperlukan pembangunan dan reformasi dalam pemerintahan lokal dan masyarakat lokal. Pemerintah daerah sendiri akan sulit untuk mereformasi dirinya sendiri, sementara itu pembangunan masyarakat lokal sendiri sangat sulit dicapai jika hanya mengandalkan usaha sendiri-sendiri, oleh karena itulah diperlukan suatu hubungan saling membangun antara pemerintah daerah dan masyarakat lokal dalam penciptaan tata pemerintahan lokal yang baik.

Mengutip Nikawa (2006), tata pemerintahan lokal mempunyai tahapan perubahan selayaknya evolusi dalam tiga tingkatan yaitu tata pemerintahan lokal responsif, kemudian berevolusi menjadi tata pemerintahan network, dan tahapan terakhir adalah tata pemerintahan lokal kemitraan. Lebih lanjut Nikawa (2006) menjelaskan:

"The responsive local governance means the good governance of local government. Responsive local governance ought to carry out its duty of responsibility and accountability for local people, and provide the chance of citizen participation. While citizen participation is increasing, local governance begins to change to the network governance.

The network governance is composed of the cooperation and responsiveness of local actors. Local actors are mutually networked and exchange their information among them. The community action group, private company, and NGOs are the actors. Also there is networking among local government and many local actors, which operate to organize the network issue and then policy network in specialized areas. This network functions in the participative decision-making process of local government, which attain more effective and efficient policy outcome.

In the network governance, the actors learn and grow in the governance partnership, providing that the local people acquire maturity as an owner and user of power and control in locality, is characterized by the equal partnership between local actors and government, the cooperation of provision of public services among them, and the effective and efficient use of local resources though this cooperation. The governance partnership will keep and secure the sustainability of community.

Dalam menuju tata pemerintahan lokal, pemerintah daerah dan masyaraka lokal harus mengubah dirinya sendiri. Pemerintah daerah merupakan elemen penting dalam kehidupan masyarakat terutama pada era desentralisasi dan harus di tranformasikan untuk mencapai tata pemerintahan lokal yang sesuai dengan tuntutan desentralisasi. 
Untuk mencapai tata pemerintahan lokal oleh pemerintah daerah, harus terdapat pengembangan kapasitas pemerintah daerah yang mencakup reformasi pemerintah daerah, peningkatan kemampuan organisasional dalam perumusan pengambilan kebijakan dan pelayanan publik, kondisi finansial pemerintah daerah yang stabil dan baik, dan pembangunan kapasitas dari pegawai negeri daerah.

Reformasi pemerintah daerah dalam beberapa hal mengadopsi beberapa langkah berikut yaitu pemangkasan biaya, restrukturisasi, privatisasi, indikator pelaksanaan tugas, dan evaluasi kebijakan. Dalam reformasi demikian, elemen yang harus diperhatikan adalah pegawai negeri daerah dan masyarakat lokal. Pengembangan kapasitas dua element tersebut sangat menentukan dalam berfungsinya tata pemerintahan lokal. Demi mencapai pengembangan kapasitas mereka, harus diberikan kesempatan untuk berpastisipasi dalam skema kemitraan di tata pemerintahan lokal.

Satu peristiwa paling dramatis di akhir abad 21 adalah pergerakan Indonesia menuju demokratisasi. Perubahan dan transisi terjadi dimana-mana di seluruh penjuru negeri, tidak dapat dipungkiri bahwa kelahiran demokrasi di Indonesia membawa cerita yang tidak selalu manis. Namun demikian, keterbukaan politik yang dirasakan belakangan ini, pertumbuhan civil society, kebebasan media dan tuntutan akuntabilitas pemerintah telah menjadi warna demokrasi Indonesia. Saat ini semua kalangan masyarakat sudah menjadi partner dan stakeholder dalam demokratisasi Indonesia.

Hal ini terlihat dari dinamika masyarakat di berbagai daerah dalam menyambut Pilkada. Pembicaraan mengenai pilkada sudah menjadi bagian dari dinamika masyarakat dan sudah menjadi suatu yang awam dibicarakan berbagai kalangan masyarakat mulai dari pasar, kampus, sampai gedung pemerintahan. Beberapa tahun penyelenggaraan Desentraliasi di Indonesia setidaknya memberikan kesempatan bagi masyarakat untuk menikmati angin demokrasi lokal yang disebut Pilkada ini.

Pilkada sebagaimana diketahui bersama merupakan bentukan dari proses desentralisasi di Indonesia dengan dasar hukum UU No. 32 Tahun 2004 mengenai Pemerintahan Daerah. Sejak 2001, Indonesia memulai kembali proses 
desentralisasi yang terhenti sejak digagas pertama kali tahun 1933 oleh Hatta dalam tulisannya "Autonomi dan Centralisasi dalam Partai" dan selama tujuh tahun ini kebijakan desentralisasi memberikan banyak warna terhadap perjalanan berbangsa dan bernegara di Indonesia. Proses desentralisasi itu sendiri merupakan proses yang sangat penting dan menentukan masa depan Indonesia; Keberhasilan dan kegagalan kebijakan ini akan memberikan dampak yang sangat besar terhadap berbagai aspek kehidupan bangsa terutama kehidupan demokrasi di Indonesia.

Demokrasi menurut Diamond harus dipandang sebagai fenomena yang berkelanjutan (Diamond: 1999). Dipandang dari perspektif ini, masa depan demokrasi adalah adalah tiada henti; elemen-elemen demokrasi akan muncul dan berkembang dalam berbagai tingkatan dan tahapan dengan tingkat kecepatan yang berbeda-beda di setiap negara. Perubahan demokrasi juga bergerak menuju arah yang berbeda, bisa menjadi semakin demokratik dan bisa juga semakin tidak demokratik. Oleh karena itulah demokrasi harus selalu diperkuat baik dengan penguatan institusi maupun penguatan civil society.

Tantangan bagi penguatan demokrasi atau konsolidasi demokrasi ini adalah bagaimana memberikan akses demokrasi kepada masyarakat dan pembentukan serta penguatan institusi-institusi demokrasi. Di titik inilah desentralisasi dengan perwujudan otonomi daerah memiliki peran yang sangat penting dalam konsolidasi demokrasi. Peran desentralisasi dalam konsolidasi demokrasi tersebut berasal dari adanya proses demokrasi yang memotivasi otoritas lokal dalam menjawab aspirasi dan kebutuhan konstituennya. Selain itu salah satu pemikiran diterapkannya desentralisasi adalah institusi demokrasi lokal akan lebih memahami dan merespon aspirasi lokal karena jika dilihat dari asfek jarak institusi dan masyarakat lokal yang dekat, mereka memiliki akses yang lebih baik terhadap informasi.

Desentralisasi bukan hanya persoalan pengaturan hubungan antar berbagai tingkatan pemerintahan namun juga merupakan persoalan mengenai hubungan antara negara dan rakyatnya. Kebijakan desentralisasi bukanlah tanggung jawab pemerintah pusat atau daerah semata namun juga merupakan tanggung jawab masyarakat lokal sebagai pihak yang memiliki hak utama dalam penyelenggaraan 
kehidupan lokal. Hal ini akan tercapai melalui lembaga perwakilan masyarakat lokal dalam wadah yang DPRD melalui proses pemilu yang bebas.

Demokratisasi di Indonesia kemudian diperkuat dengan adanya pemilihan kepala daerah secara langsung atau yang lebih dikenal dengan Pilkada mulai tahun 2005, geliat Pilkada akhir-akhir ini semakin dinamis. Pilkada merupakan institusi demokrasi lokal yang penting karena dengan Pilkada, kepala daerah yang akan memimpin daerah dalam mencapai tujuan desentralisasi akan terpilih melalui tangan-tangan masyarakat lokal secara langsung. Kepala daerah terpilih inilah yang nantinya akan menjadi pemimpin dalam pembangunan di daerah termasuk di dalamnya penguatan demokrasi lokal, penyediaan pendidikan dasar dan layanan kesehatan, perbaikan kesejahteraan rakyat, penerapan prinsip tata pemerintahan yang baik dan lain sebagainya. Bagi calon incumbent yang maju untuk kedua kalinya, Pilkada menjadi sarana masyarakat lokal untuk mengevaluasi kinerja calon selama yang bersangkutan menjabat sebagai kepala daerah.

\section{KESIMPULAN}

Meskipun banyak kritikus menyebut desentralisasi sebagai upaya perbaikan dari sentralisasi yang dijalankan oleh pemerintahan sebelumnya di Indonesia merupakan reformasi yang tidak selesai, perubahan yang significan banyak terjadi di tataran pemerintahan daerah. Perubahan tersebut adalah perubahan dari tata pemerintahan sentralistik ke tata pemerintahan lokal menuju ke arah tata pemerintahan partnership antara masyarakat lokal, lembaga swadaya masyarakat, swasta dan pemerintah daerah. Namun demikian tata pemerintahan partnership ini tampaknya masih jauh dari harapan untuk diwujudkan di Indonesia dalam waktu dekat.

Berubahnya sentralisasi menjadi desentralisasi membawa perubahan dalam sistem pemerintahan diantaranya Pilkada langsung dan Pemilu Presiden. Meskipun dirasa sebagai perubahan ke arah positif tetap saja timbul nada pesimis dan pandangan negatif dari berbagai kalangan tentang pelaksanaan pilkada di Indonesia tidak meniadakan arti pentingnya institusi ini dalam konsolidasi demokrasi di era desentralisasi ini. Saat ini bagi masyarakat lokal yang terpenting 
adalah memilih kepala daerah yang dinilai mampu untuk memimpin daerah, dengan demikian sedikit banyak akan semakin memupuk dan memperkuat demokrasi yang beranjak dewasa.

\section{DAFTAR PUSTAKA}

Darma Setyawan Alam, Otonomi daerah, 2001

Delay, S., Lamb, D. and Devas, N. 1995. 'Funding System for Daerah Percontohan', Report to the Government of Indonesia, Development Administration Group, University of Birmingham

Devas, N. (1997), 'Indonesia: What Do We Mean by Decentralization?' Public Administration and Development, 17(3): 251-68.

Diamond, Larry. 1999. Developing Democracy toward Consolidation. Baltimore and London: The John Hopkins University Press.

Dimock, E. Marshall. Administrasi Negara. Erlangga : Jakarta.

Fakrulloh Zudan dkk, Kebijakan Desentralisasi di Persimpangan, 2004.

Kansil, C.S.T dan Christine S.T Kansil. 2002. Pemerintahan Daerah Indonesia. Sinar Grafika : Jakarta

Kansil, C.S.T . 2005. Sistem Pemerintahan Indonesia. PT Bumi Aksara : Jakarta.

MaCandrews, Colin dan Ichlasul Amal. 1993. Hubungan Pusat Daerah dalam pembangunan. PT Rajagrafindo Persada : Jakarta

Ndraha, Talizidu. 1988. Metodologi Pemerintahan Indonesia. Bina Aksara : Jakarta

Nikawa, Tatsuro. 2006. "Decentralization And Local Governance: Reinforcing Democracy And Effectiveness Of Local Government". Paper presented in Regional Forum on Reinventing Government in Asia Building Trust in Government: Innovations to Improve Governance 6-8 September 2006, Seoul, Republic of Korea.

Piliang, Indra J, dkk (ed.), 2003, Otonomi Daerah, Evaluasi dan Proyeksi, Jakarta, Yayasan Harkat Bangsa bekerjasama dengan Partnership Governance Reform in Indonesia. 
Priyanto Susiloadi, Konsep Dan Isu Desentralisasi Dalam Manajemen Pemerintahan Indonesia Oktober 2007 Spirit Publik Vol 3 No 2

Prof. DR. Ir. H. A. Radi A. Gany, Rektor Universitas Hasanuddin 2003, Perspektif Pengembangan Kabupaten Soppeng Dalam RangkaMensukseskan Otonomi Daerah: Otonomi Daerah Dari Perspektif Kemandirian Lokal

Rohdewohld, R. (1995), Public Administration in Indonesia. Melbourne: Montech Pty Ltd.

Rodee, Clyner Carlton. Pengantar Ilmu Politik. 2000. PT Rajagrafindo Persada : Jakarta

Syamsuddin Haris, 2997, Desentralisasi Dan Otonomi Daerah, LIPI, Jakarta

Tjokroamidjojo, Bintoro. 1990. Pengantar Administrasi Pembangunan. LP3ES : Jakarta

Indonesia. Undang Undang Nomor 22 Tahun 1999 Tentang Pemerintahan Daerah

Indonesia. Undang Undang Nomor 25 Tahun 1999 Tentang Perimbangan Keuangan antara Pemerintah Pusat dan Pemerintah Daerah

Indonesia. Undang-Undang Nomor 32 Tahun 2004 Tentang Pemerintahan Daerah. Lembaran Negara Republik Indonesia Tahun 2004 Nomor 125.

Indonesia. Undang Undang Nomor 33 Tahun 2004 Perimbangan Keuangan antara Pemerintah Pusat dan Pemerintah Daerah

http://books.google.co.id

http://www.kompas.com

http://www.organisasi.org

http://www.scribd.com/

$\underline{\text { www.sinarharapan.co.id }}$

www.tempointeraktif.co. 